\title{
Effect of Seed Treatments on Seedling Growth of Karonda (Carissa carandas L.) cv. Local
}

\author{
J. M. Mistry* and H. H. Sitapara \\ Department of Horticulture, B. A. College of Agriculture, Anand Agricultural University, \\ Anand, Gujarat, India \\ *Corresponding author
}

\section{A B S T R A C T}

Ke y w o r d s
Growth, $\mathrm{GA}_{3}$, Cow
dung slurry,
Thiourea, Vigour
Index

\begin{abstract}
The present experiment was carried out at Horticultural Research Farm, Department of Horticulture, B. A. College of Agriculture, AAU, Anand during the year 2017-18 with the objective to study effect of different seed treatment on growth parameters of Karonda. The Experiment was laid out in completely randomized design involved 11 different seed treatments including control. Among various treatments applied, Seeds soaked in cow dung slurry for 24 hours recorded maximum seed germination (62.67\%), Seedling vigour index-I (1744) and seedling vigour index-II (74.25). Length of tap root at 60 and 90 DAS (13.80 and $17.07 \mathrm{~cm}$, respectively) was also observed maximum with the same treatment. While, seeds soaked in $\mathrm{GA}_{3} 100 \mathrm{mg} / \mathrm{l}$ for 24 hours improved various growth parameters viz., seedling length $(16.15,24.05$ and $28.43 \mathrm{~cm})$, number of leaves per seedling $(10.67$, 18.53 and 27.60) at 30, 60 and $90 \mathrm{DAS}$, number of primary roots(27.07 and 34.67) and secondary roots (32.67 and 38.67) at 60 and 90 DAS and fresh as well as dry weight of seedling (3.12 and $1.20 \mathrm{~g}$, respectively) at $90 \mathrm{DAS}$. While, seeds soaked in $\mathrm{GA}_{3} 150 \mathrm{mg} / \mathrm{l}$ for 24 hours gave significantly maximum diameter of seedling $(2.02$ and $2.29 \mathrm{~mm})$ at 60 and 90 DAS.
\end{abstract}

\section{Introduction}

Karonda (Carissa carandas L.) belongs to Apocynaceae family and is one of the important, minor underexploited fruit crop. It is originated in India with chromosome number $2 \mathrm{n}=22$. It is popularly known as "Bengal currant" or "Christ's Thorn". There are about 30 species in the genus Carissa being native of tropics and subtropics of Asia, Africa, Australia and China (Arif et al., 2016). Karonda is suitable for growing throughout subtropical and tropical climatic zones of India. Major natural areas of occurrence of karonda have been observed in the states of Maharashtra, Bihar, West Bengal, Chhattisgarh, Orissa, Gujarat, Madhya Pradesh and Rajasthan (Singh et al., 2014).It is very hardy shrub, flourishes well on lands with high temperatures and wide range of soils. It also grows successfully on marginal and wastelands. Seeds are recalcitrant and are relatively high in moisture content and possess a characteristic feature of losing their viability within 4-5 weeks. Hence, seeds of karonda should be sown just after 
extraction from fruits. The seed is quite hard and germination is low. Application of some pre-sowing treatments to the seeds affects their germination percentage and seedling growth in different fruit crops. To get higher and proper germination, seed require special treatments like scarification including soaking in water, growth regulators, concentrated acid solution etc. which helps in promotion of early and higher percentage of seed germination with healthy and vigorous seedling.

\section{Materials and Methods}

The experiment was conducted during the year of 2018 under net house (50\% shade) in College Nursery, Horticultural Research Farm, Department of Horticulture, B. A. College of Agriculture, AAU, Anand. The whole experiment comprised of 11 seed treatments viz, $\mathrm{T}_{1^{-}}$- Soaking of seeds in tap water for 24 hours; $\mathrm{T}_{2}$ - Hot water treatment $\left(60 \pm 5^{\circ} \mathrm{C}\right)$ for 10 minutes; $\mathrm{T}_{3}$-Soaking of seeds in cow dung slurry for 24 hours; $\mathrm{T}_{4}$ Soaking of seeds in cow urine $(10 \%)$ for 24 hours; $\mathrm{T}_{5}$-Seed soaking in $5 \% \mathrm{H}_{2} \mathrm{SO}_{4}$ (for 2 minutes) + wash in distilled water; $\mathrm{T}_{6^{-}}$ Soaking of seeds in $\mathrm{GA}_{3} 50 \mathrm{mg} / \mathrm{l}$ for 24 hours; $\mathrm{T}_{7}$ - Soaking of seeds in $\mathrm{GA}_{3} 100 \mathrm{mg} / \mathrm{l}$ for 24 hours; $\mathrm{T}_{8^{-}}$Soaking of seeds in $\mathrm{GA}_{3} 150 \mathrm{mg} / \mathrm{l}$ for 24 hours; $\mathrm{T}_{9}$ - Soaking of seeds in thiourea $1 \%$ for 1 hour; $\mathrm{T}_{10}$-Soaking of seeds in thiourea $2 \%$ for 1 hour; $\mathrm{T}_{11^{-}}$Control. These treatments were replicated thrice in completely randomised design. The fully ripe fruits of sweet type karonda were collected from Horticulture Research Farm of Anand Agricultural University in the month of June. The seeds were extracted and washed with water to remove the mucilaginous covering over the seed surface. The seeds were shade dried. The treated seeds were sown in polythene bags having size of $22 \times 9 \mathrm{~cm}$, previously filled with potting mixture which was prepared by mixing 1:1:1 of each soil,
FYM and vermicompost. The polythene bags were placed in flat beds with proper space. Watering of seeds was done as soon as they were sown in polythene bags. Weeding and watering were done at regular intervals whenever needed. For protection of young karonda seedlings from any fungal attack at nursery stage, Bavistin (Carbendazim 50\% WP) was drenched twice during the course of experiment. The observations regarding germination percentage, seedling length, seedling diameter, number of leaves, length of tap root, number of primary and secondary roots, fresh as well as dry weight and vigour index were taken at regular intervals.

\section{Results and Discussion}

\section{Seed germination $(\%)$}

It is evident from Table 1 that seeds soaked in cow dung slurry for 24 hours $\left(\mathrm{T}_{3}\right)$ recorded significantly the maximum germination (62.67\%) followed by treatment $T_{7}$ and $T_{6}$. This might be due to the presence of growth promoting substance (auxins) in cow dung which enhanced the germination in karonda. Similar results were obtained by Mistry and Sitapara (2020) in karonda, Shinde and Malse (2015) and Shirol et al., (2005) in khirnee, Chaudhari (2017) in mango and Parmar et al., (2018) in jackfruit.

\section{Seedling length $(\mathrm{cm})$}

The data presented in Table 1 revealed that significantly maximum length of seedling was observed at 30, 60 and 90 DAS in soaking treatment with $\mathrm{GA}_{3} 100 \mathrm{mg} / \mathrm{l}$ for 24 hours $(16.15,24.05$ and $28.43 \mathrm{~cm}$, respectively) followed by treatment with cow dung slurry for 24 hours. This is might be due to $\mathrm{GA}_{3}$ increase osmotic uptake of nutrients there by causing cell division and cell multiplication. $\mathrm{GA}_{3}$ is well known for promotion of internodal cell elongation, there by leading to 
increase in seedling length. Similar results were also obtained by Lay et al., (2015) in papaya, Rajput (2017) and Yadav et al., (2018) in custard apple.

\section{Number of leaves}

Maximum number of leaves was noticed in treatment with $\mathrm{GA}_{3} 100 \mathrm{mg} / \mathrm{l}$ for 24 hours (10.67, 18.53 and 27.60, respectively) at 30, 60 and 90 DAS, followed by treatment with cow dung slurry for 24 hours. This might be due to activity of $\mathrm{GA}_{3}$ at apical meristem, resulting in more synthesis of nucleoprotein responsible for increasing leaf initiation and leaf expansion. These results are in accordance with Nimbalkar et al., (2012), Sharma (2016) in tamarind, Palepad et al., (2017) in custard apple.

\section{Seedling diameter}

The results revealed that maximum diameter of seedling (2.02 and $2.29 \mathrm{~mm}$, respectively) was observed in soaking treatment with $\mathrm{GA}_{3}$ $150 \mathrm{mg} / \mathrm{l}$ for 24 hours at 60 and 90 DAS followed by treatments $T_{7}$ and $T_{3}$. It might be due to, $\mathrm{GA}_{3}$ increase osmotic uptake of nutrient and boost the growth by increasing cell division, cell elongation and cell multiplication in the cambium tissue of the stem portion. These results are in accordance with Ramteke et al., (2015) in aonla, Joshi et al., (2017) in chironji, Manthri and Bharad (2017) in guava.

\section{Length of Tap root}

Table 2 revealed that maximum length of tap root (13.80 and $17.07 \mathrm{~cm}$, respectively) was resulted at 60 and 90 DAS in soaking with cow dung slurry for 24 hours $\left(\mathrm{T}_{3}\right)$ followed by treatment $\mathrm{T}_{7}\left(\mathrm{GA}_{3} 100 \mathrm{mg} / \mathrm{l}\right)$. This might be due to the presence of growth promoting substances (auxins) and minerals like, N, P, $\mathrm{K}, \mathrm{Ca}, \mathrm{Mg}, \mathrm{S}$ and other micronutrients which may be contributed in increased physiological activities of seedling, essential for cell division and enlargement. These results are in accordance with Shinde and Malse (2015) in khirnee, Chaudhari (2017) in mango.

Table.1 Effect of seed treatments on germination and growth parameters of karonda seedling

\begin{tabular}{|c|c|c|c|c|c|c|c|c|c|}
\hline \multirow[t]{2}{*}{ Treatment } & \multirow[t]{2}{*}{$\underset{\%}{\text { Germination }}$} & \multicolumn{3}{|c|}{ Seedling length $(\mathrm{cm})$} & \multicolumn{3}{|c|}{$\begin{array}{c}\text { Number of leaves per } \\
\text { seedling }\end{array}$} & \multicolumn{2}{|c|}{$\begin{array}{c}\text { Seedling } \\
\text { diameter }(\mathbf{m m})\end{array}$} \\
\hline & & $\begin{array}{c}\text { 30 } \\
\text { DAS }\end{array}$ & $\begin{array}{c}60 \\
\text { DAS }\end{array}$ & 90 DAS & 30 DAS & 60 DAS & 90 DAS & 60 DAS & $\begin{array}{c}90 \\
\text { DAS }\end{array}$ \\
\hline$T_{1}$ & 45.33 & 11.38 & 18.57 & 24.36 & 7.60 & 15.20 & 21.60 & 1.83 & 2.04 \\
\hline $\mathbf{T}_{2}$ & 25.33 & 7.17 & 11.05 & 16.82 & 6.13 & 13.33 & 16.80 & 1.56 & 1.75 \\
\hline $\mathbf{T}_{3}$ & 62.67 & 14.05 & 22.80 & 27.97 & 10.13 & 17.87 & 26.53 & 1.91 & 2.16 \\
\hline $\mathbf{T}_{4}$ & 48.67 & 9.52 & 17.48 & 21.50 & 8.00 & 16.13 & 24.13 & 1.89 & 2.07 \\
\hline$T_{5}$ & 38.00 & 9.32 & 17.20 & 21.30 & 7.33 & 14.67 & 19.47 & 1.79 & 1.92 \\
\hline$T_{6}$ & 59.33 & 11.42 & 19.57 & 25.32 & 9.87 & 17.07 & 25.20 & 1.80 & 1.98 \\
\hline $\mathbf{T}_{7}$ & 60.67 & 16.15 & 24.05 & 28.43 & 10.67 & 18.53 & 27.60 & 1.96 & 2.19 \\
\hline$T_{8}$ & 49.33 & 10.43 & 18.67 & 24.12 & 8.53 & 16.53 & 24.53 & 2.02 & 2.29 \\
\hline $\mathbf{T}_{9}$ & 47.33 & 9.10 & 17.50 & 21.60 & 7.87 & 15.47 & 23.20 & 1.88 & 2.03 \\
\hline$T_{10}$ & 42.67 & 9.55 & 17.91 & 23.62 & 8.20 & 15.60 & 23.47 & 1.85 & 2.00 \\
\hline$T_{11}$ & 22.67 & 7.12 & 10.58 & 15.83 & 5.47 & 13.20 & 16.47 & 1.44 & 1.69 \\
\hline S.Em. \pm & 2.96 & 0.38 & 0.57 & 0.74 & 0.26 & 0.38 & 0.59 & 0.04 & 0.07 \\
\hline C.D. at 5\% & 8.68 & 1.12 & 1.66 & 2.16 & 0.76 & 1.12 & 1.75 & 0.12 & 0.22 \\
\hline C.V.\% & 11.24 & 6.29 & 5.53 & 5.59 & 5.51 & 4.16 & 4.58 & 3.96 & 6.31 \\
\hline
\end{tabular}


Table.2 Effect of seed treatments on root growth of karonda seedlings

\begin{tabular}{|c|c|c|c|c|c|c|}
\hline \multirow[t]{2}{*}{ Treatment } & \multicolumn{2}{|c|}{ Length of Tap root $(\mathrm{cm})$} & \multicolumn{2}{|c|}{ Number of Primary roots } & \multicolumn{2}{|c|}{ Number of Secondary roots } \\
\hline & 60 DAS & 90 DAS & 60 DAS & 90 DAS & 60 DAS & 90 DAS \\
\hline $\mathbf{T}_{1}$ & 9.70 & 11.13 & 18.00 & 21.60 & 23.73 & 27.73 \\
\hline $\mathbf{T}_{2}$ & 6.15 & 9.00 & 12.47 & 19.80 & 22.60 & 25.87 \\
\hline $\mathbf{T}_{\mathbf{3}}$ & 13.80 & 17.07 & 24.13 & 30.27 & 29.00 & 36.47 \\
\hline $\mathbf{T}_{4}$ & 8.77 & 11.00 & 20.20 & 23.00 & 26.67 & 28.87 \\
\hline $\mathbf{T}_{5}$ & 8.18 & 10.52 & 17.00 & 20.73 & 22.93 & 26.27 \\
\hline $\mathbf{T}_{6}$ & 10.26 & 14.13 & 23.73 & 28.27 & 28.27 & 35.20 \\
\hline $\mathbf{T}_{7}$ & 12.77 & 16.23 & 27.07 & 34.67 & 32.67 & 38.67 \\
\hline $\mathbf{T}_{8}$ & 9.93 & 13.47 & 22.20 & 25.87 & 27.80 & 30.87 \\
\hline $\mathbf{T}_{9}$ & 9.18 & 11.84 & 18.47 & 21.87 & 26.47 & 29.47 \\
\hline $\mathbf{T}_{10}$ & 8.82 & 11.70 & 19.27 & 23.07 & 27.00 & 30.80 \\
\hline $\mathbf{T}_{11}$ & 6.05 & 8.35 & 12.13 & 18.60 & 21.73 & 23.93 \\
\hline S.Em. \pm & 0.88 & 0.63 & 0.58 & 0.82 & 0.86 & 0.96 \\
\hline C.D. at $5 \%$ & 2.57 & 1.85 & 1.71 & 2.41 & 2.53 & 2.78 \\
\hline $\mathrm{CV} \%$ & 8.83 & 8.96 & 5.17 & 5.84 & 5.68 & 5.40 \\
\hline
\end{tabular}

Table.3 Effect of seed treatment on biomass and vigour of karonda seedling

\begin{tabular}{|c|c|c|c|c|}
\hline Treatment & $\begin{array}{c}\text { Fresh weight of } \\
\text { seedling } \mathbf{( g )}\end{array}$ & $\begin{array}{c}\text { Dry weight of } \\
\text { seedling } \mathbf{( g )}\end{array}$ & $\begin{array}{c}\text { Seedling vigour } \\
\text { index- I }\end{array}$ & $\begin{array}{c}\text { Seedling vigour } \\
\text { index- II }\end{array}$ \\
\hline $\mathbf{T}_{\mathbf{1}}$ & 2.75 & 0.68 & 1101 & 30.89 \\
\hline $\mathbf{T}_{\mathbf{2}}$ & 2.44 & 0.56 & 424 & 14.13 \\
\hline $\mathbf{T}_{\mathbf{3}}$ & 3.10 & 1.18 & 1744 & 74.25 \\
\hline $\mathbf{T}_{\mathbf{4}}$ & 2.84 & 0.91 & 1044 & 44.40 \\
\hline $\mathbf{T}_{\mathbf{5}}$ & 2.63 & 0.63 & 808 & 24.23 \\
\hline $\mathbf{T}_{\mathbf{6}}$ & 2.98 & 1.12 & 1503 & 66.71 \\
\hline $\mathbf{T}_{\mathbf{7}}$ & 3.12 & 1.20 & 1722 & 72.76 \\
\hline $\mathbf{T}_{\mathbf{8}}$ & 2.90 & 0.98 & 1201 & 48.55 \\
\hline $\mathbf{T}_{\mathbf{9}}$ & 2.81 & 0.70 & 1021 & 32.85 \\
\hline $\mathbf{T}_{\mathbf{1 0}}$ & 2.83 & 0.74 & 1006 & 31.45 \\
\hline $\mathbf{T}_{\mathbf{1 1}}$ & 2.36 & 0.52 & 358 & 11.83 \\
\hline S.Em. $\mathbf{\pm}$ & 0.08 & 0.04 & 73.92 & 3.62 \\
\hline C.D. at 5\% & 0.23 & 0.11 & 216.81 & 10.61 \\
\hline C.V.\% & 4.81 & 7.75 & 11.80 & 15.25 \\
\hline
\end{tabular}

\section{Number of primary roots}

The data presented in Table 2 indicated that highest number of primary roots $(27.07$ and 34.67 , respectively) was observed at 60 and 90 DAS in treatment with $\mathrm{GA}_{3} 100 \mathrm{mg} / \mathrm{l}$ for
24 hours which was superior over all the treatments. Vigorous root growth due to $\mathrm{GA}_{3}$ might have resulted in more production of photosynthates and their translocation through phloem to the root zone, which might be responsible for increase in number of primary 
roots. Similar results are in line with the findings of Patel et al., (2016) in mango, Dhawale (2015) in tamarind and Anjanawe et al., (2013) in papaya.

\section{Number of secondary roots}

It is evident from Table 2 that soaking treatment of $\mathrm{GA}_{3} 100 \mathrm{mg} / \mathrm{l}$ for 24 hours recorded the highest number of secondary roots (32.67 and 38.67, respectively) at 60 and 90 DAS.GA $_{3}$ might be increase auxin level in the roots which stimulates more root initiation, more nutrient uptake and more translocation of photosynthates to root zone resulting in increased number of secondary roots. These results are in line with Anjanawe et al., (2013) in papaya, Dilipet al., (2017) in rangpur lime and Rajput (2017) in custard apple.

\section{Fresh weight of plant}

It is evident from Table 3 that maximum fresh weight of seedling recorded in treatment with $\mathrm{GA}_{3} 100 \mathrm{mg} / \mathrm{l}$ for 24 hours $(3.12 \mathrm{~g}$ ) which was followed by treatments $T_{3}, T_{6}$ and $T_{8}$ at 90 DAS. GA 3 influenceson different plant parts, stimulating cell division, cell elongation, auxin metabolism, cell wall plasticity and permeability of cell membrane leading to enhanced growth. Similar results were also obtained by Anjanawe et al., (2013) in papaya, Vasantha et al., (2014) tamarind, Jaiswal et al., (2018) in kagzi lime and Verma et al., (2019) in aonla.

\section{Dry weight of seedling}

The data presented in Table 3 revealed that $\mathrm{GA}_{3} 100 \mathrm{mg} / \mathrm{l}$ for 24 hours $(1.20 \mathrm{~g})$ recorded significantly maximum dry weight of seedling followed by treatment $\mathrm{T}_{3}$ and $\mathrm{T}_{6}$ at $90 \mathrm{DAS}$. Increase in dry weight of seedling is a result of improved mobilization of nutrients due to the application of $\mathrm{GA}_{3}$, which might have promote more production of photosynthetic product and translocate them to various plant parts which might have resulted in better plant growth and development. These results are in line with Vasantha et al., (2014) in tamarind, Joshi et al., (2017) in chironji and Verma et al., (2019) in aonla.

\section{Seedling vigour index-I}

Table 3 revealed that soaking treatment with cow dung slurry for 24 hours showed significantly maximum seedling vigour indexI (1744)at 90 DAS which was followed by $\mathrm{GA}_{3} 100 \mathrm{mg} / \mathrm{l}$ for 24 hour (1722).This is might be due to increased germination and seedling length which have contributed to higher seedling vigour index-I. These results are in accordance with Gurung et al., (2014) in passion fruit, Chaudhari (2017) in mango and Rajput (2017) in custard apple.

\section{Seedling vigour index-II}

It is evident from Table 3 that soaking treatment with cow dung slurry for 24 hours showed significantly maximum seedling vigour index-II (74.25) at 90 DAS followed by $\mathrm{GA}_{3} 100 \mathrm{mg} / \mathrm{l}$ and $\mathrm{GA}_{3} 50 \mathrm{mg} / \mathrm{l}$ for 24 hours (72.76 and 66.71, respectively). The reason might be attributed to the increased dry matter production along with higher germination in seeds treated with cow dung slurry improve seedling vigour index-II. These results are in accordance with Rajput (2017) in custard apple.

Based on the results, it can be concluded that application of cow dung slurry as seed soaking treatment to karonda seeds for 24 hours was most effective in increasing the seed germination. It also gave significant effect by maximizing the length of tap root and improve seedling vigour index-I as well as seedling vigour index-II. The maximum growth of the seedling was observed in seed 
soaking treatment with $\mathrm{GA}_{3} 100 \mathrm{mg} / \mathrm{l}$ for 24 hours. However, seed soaking treatment with $\mathrm{GA}_{3} \quad 150 \mathrm{mg} / \mathrm{l}$ for 24 hours significantly maximized the diameter of karonda seedlings.

\section{References}

Anjanawe, S. R., Kanpure, R. N., Kachouli, B. K. and Mandloi, D. S. (2013). Effect of plant growth regulators and growth media on seed germination and growth vigour of papaya. Ann. Plant Soil Res., 15(1): 31-34.

Arif, M., Kamal, M., Jawaid, T., Khalid, M., Saini, K. S., Kumar, A. and Ahmad, M. (2016). Carissa carandas Linn. (Karonda): An exotic minor plant fruit with immense value in nutraceutical and pharmaceutical industries, Asian J. Biochem. Pharma. Sci., 6(8): 14-19.

Chaudhari, T. M. (2017). Effect of water, cow dung slurry and cow urine on mango (Mangifera indical.) stones cv. Rajapuri under protected condition. A Thesis submitted to Junagadh Agricultural University, Junagadh (Gujarat).

Dhawale, U. (2015). Effect of plant growth regulators on seed germination, growth of seedling and survival of tamarind (Tamarindus indica L.). A Thesis submitted to Jawaharlal Nehru Krishi Vishwa Vidhyalaya, Jabalpur (Madhya Pradesh).

Dilip, W. S., Singh, D., Moharana, D., Rout, S. and Patra, S. S. (2017). Effect of gibberellic acid (GA) different concentrations at different time intervals on seed germination and seedling growth of Rangpur lime. $J$. Agroecology Natural Resour. Manag, 4(2): 157-165.

Gurung, N., Swamy, S. K., Sarkar, S. K. and Ubale, N. B. (2014). Effect of chemicals and growth regulators on germination, vigour and growth of passion fruit (Passiflora edulis Sims.). The Bioscan, 9(1), 155-157.

Jaiswal, S. B., Nainwad, R. V., Supekar, S. J. and Mane, S. B. (2018). Effect of growth regulators and chemicals on growth of Kagzi lime (Citrus aurantifolia Swingle.) seedlings. Int. J. Curr. Microbiol. App. Sci., Special Issue-6, 940-944

Joshi, C. J., Sharma, D. K., Gotur, M. and Rajan, R. (2017). Effect of different chemicals on seedling growth and biomass of chironji (Buchanania lazan Spreng.). Int. J. Curr.Microbiol. App. Sci., 6(9):1819-1823.

Lay, P., Basvaraju, G. V., Pashte, V. V. and Gowri, M. (2015). Studies on effect of gibberellic acid $\left(\mathrm{GA}_{3}\right)$ and potassium nitrate $\left(\mathrm{KNO}_{3}\right)$ on breaking of seed dormancy of papaya (Carica papaya L.) cv. Surya. The Bioscan, 9(1 and 2):111-115.

Manthri, K. and Bharad, S. G. (2017). Effect of pre sowing seed treatments on growth pattern of guava variety L-49. Int. J. Chem. Studies, 5(5): 1735-1740.

Mistry, J. M. and Sitapara, H. H. (2020). Effect of seed treatments on germination of karonda (Carissa carandas L.) cv. Local. Int. J. Chem. Studies, 8 (4):3174-3176.

Nimbalkar, S. D., Jadhav, Y. S., Adat, S. S. and Savvashe, A. Y. (2012). Effect of different seed treatments on germination and growth of karonda (Carissa congesta W.) seedlings. Green Farming, 3(3): 340-342.

Palepad, K. B., Bharad, S. G. and Bansode, G. S. (2017). Effect of seed treatments on germination, seedling vigour and growth rate of custard apple (Annonas quamosa). J. Pharmacognosy Phytochem. 6(5): 20-23.

Panse, V. G. and Sukhatme, P. V. (1967). Statistical methods for Agricultural Workers, ICAR Publication, New 
Delhi, pp. 167-174.

Parmar, B. R., Patel, F., Parmar, A. B. and Pandey, A. K. (2018). Effect of organic compounds on seed germination and seedling growth of jack fruit (Artocarpus heterophyllus Lam.) seed. PharmaInno. J., 7(10): 702-704.

Patel, R. J., Ahlawat, T. R., Singh, A., Momin, S. K. and Chaudhri, G. (2016). Effect of pre-sowing treatments on stone germination and shoot growth of mango (Mangifera indica L.) seedlings. Int. J. Agri. Sci., 8(52): 2437-2440.

Rajput, K. (2017). Effect of organic and inorganic sources on seed germination, growth and survival of custard apple (Annonas quamosa L.) seedlings. A Thesis submitted to Jawaharlal Nehru Krishi Vishwa Vidhyalaya, Jabalpur (Madhya Pradesh).

Ramteke, N., Paithankar, D. H., Kamatyantti, M., Baghel, M. M., Chauhan, J. and Kurrey, V. (2015). Seed germination and seedling growth of papaya as influenced by $\mathrm{GA}_{3}$ and propagation media. Int. J. Farm Sci., 5(3): 74-81.

Sharma, D. K. (2016). Effect of growth regulators, biofertilizer and scarification on germination and seedling growth of tamarind. Adv. Life Sci., 5(7): 2818-2823.

Shinde, V. V. and Malshe, K. V. (2015). Effect of cattle urine and cowdung slurry as seed treatment on germination and growth of khirni (Manilkara hexandra L.). J. Eco-friendlyAgri., 10(2): 128-130.

Shirol, A. M., Hanamashetti, S. I., Kanamadi, V. C., Thammaiah, N. and PatilS. (2005). Studies on pre-soaking, method and season of grafting of sapota rootstock khirnee. Karnataka J. Agri. Sci., 18(1):96-100.

Singh, S., Singh, A. K., Meghwal, P. R., Singh, S. and Swamy, G. S. K.(2014). Tropical and Subtropical Fruit Crops: Crop Improvement and Varietal Wealth, Jaya Publishing House, Delhi pp. 387-400.

Vasantha, R. T., Vijendrakumar, R. C., Guruprasad, T. R., Mahadevamma, M. and Santhosh, K. V. (2014). Studies on effect of growth regulators and biofertilizers on seed germination and seedling growth of tamarind (Tamarindus indica L.). Plant Archives, 14(1): 155-160.

Verma, R., Pandey, C. S., Pandey, S. K. and Sahu, K. (2019). Influence of presowing seed treatment and growing conditions on growth performance of Indian gooseberry seedlings (Emblica officinalis Gaertn). Int.J.Curr. Microbiol. App. Sci., 8(3):1936-1948.

Yadav, R. S., Sharma, T. R., Pandey, S. K. and Maske, G. (2018). Effect of $\mathrm{GA}_{3}$ and cow urine on germination and morphology of custard apple. Int. J. of Chem. Studies, 6(4): 1131-1134

\section{How to cite this article:}

Mistry, J. M. and Sitapara, H. H. 2020. Effect of Seed Treatments on Seedling Growth of Karonda (Carissa carandas L.) cv. Local. Int.J.Curr.Microbiol.App.Sci. 9(12): 1980-1986. doi: https://doi.org/10.20546/ijcmas.2020.912.234 